\title{
OBERTURA PARA UN DRAMA MUSICAL
}

Overture for a tragic drama

\author{
Paulina Rivero Weber
}

Universidad Nacional Autónoma de México (UNAM)

RESUMEN: Así habló Zaratustra es una obra musical en el sentido nietzscheano de la expresión. Si hemos de preguntarnos a qué forma musical pertenece, el mismo Nietzsche dejó abiertas dos posibilidades: la sinfonía o el drama trágico. Tomando como base la propuesta de El nacimiento de la tragedia, La gaya ciencia, los fragmentos póstumos y su correspondencia, en este escrito se apuesta por la segunda de estas posibilidades. De ahí que se aboque a mostrar en qué sentido el Prólogo de esta obra es una totalidad que contiene en germen la obra entera, esto es: una obertura musical.

Palabras clave: música - prólogo - claves - filosofía

ABSTRACT: Thus Spoke Zarathustra is a musical work in the Nietzschean sense of the term. If we ask to what musical form it belongs, Nietzsche himself left open two possibilities: the symphony or the tragic drama. Based on the proposal of The Birth of Tragedy, Gay Science, the posthumous fragments, and his correspondence, this paper is committed to the second of these possibilities. Hence, it's devoted to show in what sense the Prologue of this work is a totality which contains the seed of the whole work, namely that the Prologue is a musical overture.

Keywords: Music - Prologue - Clues - Philosophy

Pues bien, llamaos aquí con ánimo conmovido a las puertas del presente y del futuro: ¿conducirá esa «transmutación» a configuraciones siempre nuevas del genio, y precisamente del Sócrates que cultiva la música? ${ }^{1}$

Acaso sería lícito considerar al Zaratustra entero como música...2

Proponer un cambio radical en la forma de hacer filosofía es un atrevimiento. Pero hacerlo y al mismo tiempo llevar a cabo la propuesta, es algo que solamente un genio podría hacer: tal genio fue Friedrich Nietzsche. Desde el párrafo inicial de su primera obra ya estaba ahí la propuesta y su realización. En él, el joven de 24 años dice:

1. F. Nietzsche, El nacimiento de la tragedia, OC I 398, sec. 15.

2. F. Nietzsche, Ecce Homo, "Así habló Zaratustra», Alianza, 1998, p. 93. 
Mucho habremos ganado para la ciencia estética cuando hayamos llegado no solo al discernimiento lógico, sino a la seguridad inmediata de la intuición de que el desarrollo continuado del arte está ligado a la duplicidad de lo apolíneo y lo dionisíaco: de forma similar a como la generación depende de la dualidad de sexos, en lucha permanente y en reconciliación que solo se produce periódicamente ${ }^{3}$.

La propuesta consiste en abandonar la excesiva preocupación por el discernimiento lógico; no dejarla de lado, pero asumir que no se trata «solo" de eso; es necesario en cambio llegar a la «seguridad inmediata de la intuición». Para ello la filosofía habrá de convertirse en algo diferente, deberá abandonar su afán cientificista para acercarse al mundo del arte y convertirse, ella misma, en arte. El mito, el símbolo y la metáfora serán herramientas tan importantes para este Sócrates musical como la lógica lo es para el positivista. Desde esa primera obra se «conmovía el ánimo» del joven pensador al imaginar un futuro con un Sócrates cultivador de la música, un filósofo capaz de pensar de manera musical: tal futuro llegó con Así habló Zaratustra.

El Zaratustra es una obra musical. Esa idea, recurrente en sus intérpretes, pertenece al mismo Nietzsche, quien también introdujo un problema que aun hoy nos ocupa: de tratarse de una obra musical, ¿̇a qué forma estaría obedeciendo el Zaratustra nietzscheano: se trata de una ópera o una sinfonía? Nietzsche dejó esta anfibología por escrito, como si no pudiera definirse al respecto, tal y como sucede por ejemplo en la carta que acompaña la entrega de la tercera parte de la obra, dirigida a su editor E. Schmeitzner: «Esta tercera parte de mi drama (mejor sería definirla como sinfonía) tiene una extensión igual (según un cálculo bastante preciso) a la segunda...»"

¿Drama o sinfonía? Graham Parkes, entre otros especialistas, ha analizado la posibilidad de concebir la obra como una sinfonía, aunque en realidad pareciera estar a favor de simplemente leerla como música, como puede apreciarse en las conclusiones de su trabajo ${ }^{5}$. De ese mismo tenor sería lo opinión de Curt Paul Janz, quien en su biografía concluye que hasta cierto punto esa obra puede pensarse como una sinfonía, pero que uno debe primero olvidarse por completo de la concepción formal de «la sinfonía», a favor de «la música en general» ${ }^{6}$. Por su parte, Roger Hollinrake en Nietzsche, Wagner and the Philosophy of Pessimism ${ }^{7}$, analiza la obra teniendo en mente la estructura de la ópera wagneriana para ubicar Así habló Zaratustra en relación al El nacimiento de la tragedia y a la influencia de Wagner en Nietzsche ${ }^{8}$.

3. F. Nietzsche, El nacimiento de la tragedia, sec. 1, primer párrafo de la obra. OC I 338.

4. Carta a E. Schmeitzner, 18 de enero de 1884 (CO IV 427-428).

5. G. Parkes, «The Symphonic Structure of Thus Spoke Zarathustra: A Preliminary Outline», en J. Luchte, Nietzsche's 'Thus Spoke Zarathustra': Before Sunrise, London/New York: Continuum, 2008, cap. I.

6. C. P. Janz, Nietzsche, vol. 2, trad. de J. Muñoz e I. Reguera, Madrid: Alianza, 1981: «¿Es Zaratustra una sinfonía?», pp. 167-195.

7. R. Hollinrake, Nietzsche, Wagner and the Philosophy of Pessimism, London/New York: Routledge, 2010.

8. Al hablar de la interpretación musical de la obra de Nietzsche es imposible no reconocer el trabajo de Michael Allen Gillespie, quien considera que en sus últimos trabajos Nietzsche emplea formas musicales para coordinar una variedad de aforismos en un ámbito más amplio, y demuestra que 
En este trabajo mostraré las razones por las que considero que, más allá de la relación con Wagner y el drama musical, y más allá de la idea nietzscheana de la sinfonía, Así habló Zaratustra es un drama musical en el sentido nietzscheano del término. Para este drama musical, Nietzsche escribió una obertura en la que anunció los motivos melódicos que se desarrollarían a lo largo de la obra, papel que cumple toda obertura ${ }^{9}$. En palabras más claras: sostengo aquí que el prólogo de Así habló Zaratustra es una unidad total en la cual se esbozan las ideas que Nietzsche desarrollará a lo largo de la obra.

Veamos primeramente el significado de la expresión «drama musical» en el sentido nietzscheano. Esta se compone de dos vocablos y cada uno de ellos designa los dos ámbitos necesarios para la existencia de la tragedia. Como lo mostró de manera nítida en El nacimiento de la tragedia, es la conjunción de drama y música lo que crea la tragedia. Esta nace de un elemento dionisíaco: el coro musical, y cuando este se vacía en el escenario, surge la transfiguración apolínea: el drama. Ambos aspectos, drama y música, conforman la tragedia griega, la cual en algún momento de su vida Nietzsche consideró que podría renacer en la obra de Richard Wagner ${ }^{10}$. De manera que «drama musical» no quiere decir otra cosa que «tragedia».

Así habló Zaratustra es en ese sentido una tragedia y como tal, es dionisíacoapolínea: el drama apolíneo está presente a través de las imágenes de sus personajes, y el trasfondo dionisíaco en su «sabiduría salvaje». Esto está en plena consonancia con la obra anterior a su Zaratustra, cuyo último capítulo se titula Incipit tragoedia. Dicho capítulo corresponde textualmente al primero del Prólogo de Así habló Zaratustra, y es, como quedó indicado en la forma en que lo tituló en La gaya ciencia, el que da inicio a este drama musical, esto es, a esta especie de renacimiento de la tragedia griega ya no en manos de Wagner, sino del mismo Nietzsche.

Si hubiese que fundamentar más la tesis de que tratamos con una obra trágica, esto es, con un drama musical, podríamos recordar también que en esta obra $\mathrm{Za}$ ratustra habla consigo mismo el lenguaje del ditirambo ${ }^{11}$, esto es, el lenguaje que se cantó en el origen universal de la ópera: el lenguaje de la tragedia griega. En ese sentido, el Zaratustra nietzscheano es el héroe de la gran tragedia griega escrita por Nietzsche. La aparición de Zaratustra en la obra nietzscheana es el comienzo de la tragedia en el sentido griego, que es el sentido nietzscheano: el drama musical dionisíaco-apolíneo, origen de cualquier ópera posible.

De ser verdad lo anterior, el Prólogo sería la obertura a un drama musical en cuatro partes, y como tal, presentaría todas las líneas melódicas que contiene

El ocaso de los ídolos está compuesto en la forma de una sonata. Cf. "Nietzsche's musical Politics», en M. A. Gillespie y T. B. Strong (eds.), Nietzsche's New Seas, Explorations in Philosophy, Aesthetics, and Politics, Chicago: University of Chicago Press, 1988, p. 119.

9. Aunque han llegado a existir piezas musicales independientes llamadas «oberturas», como es el caso de la Obertura Las Hébridas de F. Mendelssohn, o de la Obertura 1812 de Tchaikovski, por lo general esta es — como bien lo indica su nombre - una apertura: el momento en que se abre la obra al que escucha y se le presentan los motivos melódicos que se desarrollarán a lo largo de la obra. En particular, el papel de la obertura fue fundamental para Richard Wagner, dato que Nietzsche evidentemente no podía desconocer.

10. Cf. El nacimiento de la tragedia, particularmente sus cinco últimos capítulos.

11. EH, "Así habló Zaratustra», 7. 
la obra en su conjunto. A continuación se expondrán los temas musicales que aparecen en esa obertura, las ideas-motivo que anuncian la filosofía de toda la obra en los diez apartados del Prólogo.

Es usual interpretar las primeras líneas de esta obra como una inversión del Evangelio de Lucas $(3,23)$ : a los treinta años, Jesús va a la multitud mientras que a esa misma edad Zaratustra hace justo lo contrario; se retira de ella. Esa puede ser una asociación válida, ya que a lo largo de la obra aparecerán varias alusiones irónicas a la Biblia: Zaratustra sería entonces una especie de Anticristo en el sentido nietzscheano, un sabio dionisíaco que predica lo contrario a los principios cristianos. A pesar de lo anterior me interesa señalar que en un fragmento póstumo de 1881 se revela una asociación que resulta enriquecedora: «Zaratustra, nacido en el lago Urmi, al cumplir los treinta años abandonó su hogar, fue a la provincia de Aria y escribió, en diez años de soledad, el Zend-Avesta». Eso es lo que Nietzsche creía, y no interesa tanto el Zaratustra "histórico»: lo relevante es el Zaratustra histórico de Nietzsche, por un lado, y, por otro lado, el Zaratustra como el personaje de toda la obra, el cual se contrapone a su Zaratustra histórico ${ }^{12}$. Al igual que el Zaratustra «histórico» de Nietzsche, a los treinta años el Zaratustra nietzscheano se retira por diez años. Pero no escribe una obra magna para crear una nueva religión, sino que se transforma a sí mismo en un ser que siente la imperiosa necesidad de dar marcha atrás de toda religión y transformar a los demás. Como lo dice el mismo Nietzsche al referirse a esta obra: «No habla en él un 'profeta', uno de esos espantosos híbridos de enfermedad y de voluntad de poder denominados fundadores de religiones. [...] No habla aquí un fanático, aquí no se 'predica', aquí no se exige fe.... ${ }^{13}$. Y podríamos agregar: aquí habla un ex profeta que se retracta de la fundación de su religión:

No se me ha preguntado, pero debería habérseme preguntado qué significa cabalmente en mi boca, en boca del primer inmoralista, el nombre Zaratustra [...] Zaratustra fue el primero en advertir que la auténtica rueda que hace moverse a las cosas

12. En su ya citada obra, Hollinrake ha hecho notar que Nietzsche sabía que Zoroastro había sido presentado por muchos helenistas como el padre de la filosofía. Esto lo corroboramos si tenemos en cuenta que la referencia más temprana a Zoroastro aparece en unas notas que datan de 1867-1868, «Zum Prooem des Laertius». La cita de Laercio dice: «Antístenes — este compuso diez volúmenes: en primer lugar... Sobre los magos. Habla de Zoroastro, un mago que descubrió la sabiduría; algunos atribuyen esto a Aristóteles, otros a Antístenes de Rodas» [cf. Laercio VI 19]. Nietzsche cita esa fuente en el capítulo VI de «Sobre Laercio y Hesiquio», de su tratado «Sobre las fuentes de Diogenes Laercio» que se escribe en 1868 (no en 1867). Al respecto cf. J. Duchesne-Guillemin, The Western Response to Zoroaster, Oxford, 1958, pp. 75 ss. Por otro lado, conviene recordar que ese Sócrates «histórico» de Nietzsche está influenciado en gran medida por la obra de Friedrich Creutzer Symbolik und Mythologie der alten Völker, 3. ${ }^{a}$ ed., 4 vols., Leipzig/Darmstadt, 1836-1843, la cual se encuentra listada en el inventario de su biblioteca (N-Bibliothek 10), como lo señala el mismo Hollinrake. Y deriva también de Spiegel, Eranische Alterthumskunde, 3 vols., Leipzig, 1850, quien fue uno de los primeros en tratar el zoroastrismo académicamente.

13. EH, Prólogo, 4 
es la lucha entre el bien y el mal, la trasposición de la moral a lo metafísico, como fuerza, causa, fin en sí, es obra suya. Mas esa pregunta sería ya, en el fondo, la respuesta. Zaratustra creó ese error, el más fatal de todos, la moral; en consecuencia, también él tiene que ser el primero en reconocerlo ${ }^{14}$.

Zaratustra es desde el primero momento del Prólogo el negador de la moral. Y enseguida aparece el fundamento de las nuevas tablas de valores zaratustrianas, nuestro segundo gran tema musical: Zaratustra es un ser sobreabundante que se ha transformado en un donador, lo cual tiene una importancia que no puede exagerarse: la primera acción de este héroe es invocar al Sol: «iGran Astro! iQué sería de tu felicidad si no tuvieras a aquellos a quienes iluminas!» ${ }^{15}$. La idea de la autodonación a raíz de la sobreabundancia es una idea clave de la obra y aparece en ese primer párrafo del Prólogo. Zaratustra se siente tan pleno como el Sol y requiere por lo mismo alguien a quien donar el beneficio, como lo hace el Sol que se le entrega a él día a día. Es de capital importancia que la obra arranque con este tema, pues solo comprendiendo en qué consiste la autodonación por sobreabundancia es posible interpretar su crítica a la compasión. Al igual que el Sol, Zaratustra necesita dar, mas no da por compasión sino por la honda necesidad que surge de su sobreabundancia, como una copa que rebosa y necesita vaciarse: he ahí a dónde conduce el egoísmo como Nietzsche lo entiende. Zaratustra se aísla en sí mismo por diez años y ese egoísmo le lleva a requerir dar todo cuanto sabe, todo cuanto es: para Nietzsche la única vía válida para el altruismo, es el egoísmo; solamente aquel que se ha transformado tiene esa necesidad - y esa capacidad- de donarse a sí mismo en sobreabundancia.

Una tercera línea musical de este primer apartado del Prólogo es apenas sugerida: de modo similar al citado parágrafo de El nacimiento de la tragedia, desde este primer momento aparece el tono musical que sugiere ya su idea más radical. En efecto, el águila y la serpiente son mencionadas en el tercer párrafo de este primer parágrafo, y reaparecerán en el parágrafo diez como una especie de premonición del eterno retorno de lo mismo en las metáforas del águila que vuela en círculos y la serpiente enroscada sobre sí formando un anillo.

Es importante notar que la cueva de donde sale Zaratustra - y esta es una diferencia radical con respecto a la caverna platónica - se ubica en lo alto de una montaña, por encima del resto de la humanidad. Él no decide descender de ella como un compromiso ético-político, como es el caso del descenso platónico hacia la cueva, la cual es, por cierto, subterránea, y no elevada como la de Zaratustra. Más que un compromiso, en Zaratustra hay una necesidad propia dictada por la sobreabundancia. Ambos descensos, el platónico y el zaratustriano, tienen como finalidad transformar a la humanidad y con ella, al mundo, como lo ha hecho notar Martha Kendal ${ }^{16}$. Ambos son descensos peligrosos, pues implican el intento

14. EH, «Por qué soy un destino», 3 .

15. La invocación al Sol se repetirá al final de la obra en el capítulo titulado «El signo».

16. Kendal lleva este paralelismo hasta el punto de afirmar que el descenso de Sócrates al Pireo al inicio de República corresponde al descenso de Zaratustra de su montaña. En su afán de encontrar similitudes, olvida las diferencias, que son las que enriquecen una interpretación. M. Kendal Woodruff, «Untergang und Übergang: The Tragic Descent of Socrates and Zarathustra»: The Journal of Nietzsche Studies 34 (otoño de 2007), 61-78. 
de despertar a quienes muy bien pueden desear no hacerlo. Es evidente que Platón tenía en mente la muerte de Sócrates tramada por el Estado, ya que su juicio fue eminentemente político ${ }^{17}$. Zaratustra encontrará en cambio un populacho que le detestará y le amenazará, como veremos al final del Prólogo. Hay, pues, coincidencias, pero la diferencia es sin embargo capital: el descenso platónico de regreso a la caverna parte desde el mundo inteligible hacia el mundo sensible, en donde se encuentra presa la humanidad, a la que es necesario liberar y conducirla hacia el mundo inteligible y con ello al «Bien». El descenso zaratustriano nada tiene que ver con lo anterior; él no desciende del mundo inteligible sino de la soledad que le ha transformado en un ser sensible y ha aprendido que el espíritu es cuerpo, como dirá más adelante. Desciende en un intento de sensibilizar al otro, de corporeizarlo o hacerle consciente de que es cuerpo, podríamos decir. No pretende hacer que quienes le escuchen vivan un proceso inteligible, sino precisamente uno sensible. No pretende educar, o en todo caso se trataría de una educación estética de la humanidad. La caverna de Zaratustra se ubica, como decíamos, en la montaña; metáfora del lugar más elevado axiológicamente, porque ahí ha encontrado el crecimiento que solo puede darse en soledad.

Por otro lado aparece finalmente en este primer apartado la idea del ocaso: Zaratustra desciende como el Sol y con ello inicia su ocaso, para volver a nacer: todo el libro es la narración del ocaso de Zaratustra hasta su renacimiento simbolizado por el Sol naciente del último capítulo de la obra: «Esta es mi mañana, $m i$ día comienza: iArriba ahora, asciende gran mediodía!» ${ }^{18}$. El descenso que cada día lleva a cabo el Sol, ese «ir hacia abajo» (untergehen) es metáfora de la necesidad de morir para volver a nacer como superhombre. La imagen del descenso del Sol será una metáfora en algunos momentos ambigua a lo largo de esta obra, pero por lo general aludirá a esa necesidad de morir para transformarse, ideal que podría surgir de casi cualquier texto budista y como veremos, esa no es la única cercanía al budismo en esta obra.

Comienza pues el descenso de Zaratustra, el Untergehen necesario para la aurora del nuevo hombre. Su primer encuentro es con un hombre santo, el mismo que después será personificado en la imagen del camello, que carga heroicamente con valores ajenos. El santo reconoce a Zaratustra y su transformación: los viejos valores, simbolizados en las cenizas, son ahora fuego: son nuevos valores incendiarios. Por eso le previene: «¿No temes la pena que recae en el incendiario?»; aquel que pretende cambiar los valores morales ha de pagar por ello, como pronto Zaratustra lo sabrá. Por primera vez se menciona al bailarín y al niño: aluden respectivamente a la ligereza y la inocencia. Que el hombre santo considere que Zaratustra es un bailarín y un niño es sumamente importante: la ligereza será la propuesta con la que Nietzsche transforma su estudio sobre la tragedia y la vida trágica: es necesario aprender a ser ligeros, a no dejarse arrastrar por el espíritu

17. Al respecto es fundamental la obra de G. Luri Medrano, El proceso de Sócrates, Madrid: Trotta, 1998.

18. Za IV, «El enigma», Alianza, 1998. 
de la pesadez. La idea de la ligereza es fundamental en esta obra tanto como en el pensamiento de Nietzsche. La ligereza y la superficie no deben entenderse en el sentido de lo meramente superficial, pues aluden a la capacidad de levantar el vuelo y ser capaz de no caer. La ligereza nietzscheana, como lo ha indicado Luis de Santiago, puede ser la misma que la de la música de Mozart ${ }^{19}$, la cual posee una ligereza casi sagrada, dirá de Santiago en el ya clásico Arte y poder. Ser ligero implica ser capaz de volar, ser alado: solamente un ser así es capaz de sobrevolar el abismo de la ausencia de valores sin sucumbir a él: que no construya su nido sobre un abismo. Manuel Barrios y Jaime Aspiunza hacen una interesante reflexión al respecto:

... con la fórmula das leichte Leben Nietzsche está traduciendo la expresión empleada por Homero (Ilíada, 6, 138; Odisea, 4, 805) para referirse a los dioses griegos, rheia zôontes, esto es, los que viven sin esfuerzo, aliviados de la pesadez, dificultad o carácter gravoso de la vida de los mortales. [...] La vida de los dioses es, por tanto, puro vivir, vida ligera, fácil o leve - e incluso, en cierta medida, frívola y jovial. Cuando Nietzsche habla de buscar un nuevo centro de gravedad y de afirmar el pensamiento del eterno retorno, «la más pesada carga», sigue jugando en idéntico sentido con este contraste entre el peso y la levedad... ${ }^{20}$.

Por su parte, como sabemos, el «niño» es la metáfora de la inocencia del devenir y la aceptación trágica de ese hecho, que solo el superhombre es capaz de asumir. El niño en ese sentido es una imagen más del superhombre: pensemos en el apartado inicial del libro I, «De las tres transformaciones del espíritu», en donde la última transformación es la del niño, o recordemos en el niño que juega junto al mar que le traerá conchas multicolores. Por eso el santo le llama «un despierto», alusión clara a la budeidad ${ }^{21}$. ¿Para qué descender a los hombres? Pregunta el santo: «ंquieres volver a arrastrar tu cuerpo?»; el riesgo de arrastrar el cuerpo implica perder esa ligereza propia de la budeidad: caer bajo el peso de la pesantez.

La respuesta de Zaratustra brinda nuevas claves: el santo se ha alejado de la humanidad y ahora ella duda de él: para la multitud el hombre sabio es sospechosamente solitario como podría serlo un ladrón. Por eso se ha quedado como eremita, por eso es «un oso entre los osos, un pájaro entre los pájaros» dedicado a alabar a dios. De modo contrastante Zaratustra quiere buscar a la humanidad para hacerle un regalo, no una limosna: su gran amor. Con ello nuevamente aparece el tema de la donación de sí mismo, de regalarse a sí. Zaratustra comprende que el único sentido de la vida del hombre santo es alabar a Dios, y por lo mismo decide acabar con este encuentro: «iQué tendría yo para daros a vosotros! iPero deja me vaya de prisa para que no os quite nada!». En esa precaución de no quitarle nada al hombre santo, Nietzsche anuncia por vez primera en este libro la muerte de Dios, presentando a un Zaratustra sorprendido ante la ingenuidad del hombre santo: « iCómo es posible! iEste viejo santo aun no ha oído nada en su bosque de que Dios ha muerto!».

19. L. E. de Santiago Guervós, Arte y poder, aproximación a la estética de Nietzsche, Madrid: Trotta, 2004.

20. FP II 187.

21. Como sabemos, Nietzsche leyó el libro Buddha. Sein Leben, seine Lehre, seine Gemeinde, de Hermann Oldenberg (Berlin, 1881). 
La muerte de Dios ya había sido expuesta en el apartado 125 de La gaya ciencia. De hecho Hegel había empleado esta metáfora al igual que otros poetas como Jean-Paul Richter y posteriormente Novalis ${ }^{22}$. Como bien lo ha señalado Heidegger, el Dios cristiano que muere en la obra de Nietzsche representa el mundo suprasensible. Ese mundo fue contrapuesto por Platón al mundo sensible que es este mundo en el que vivimos. Para Nietzsche el cristianismo es platonismo simplificado para el pueblo; de ahí que la muerte de Dios sea no solamente la muerte del Dios cristiano, sino el fin del mundo suprasensible, a saber: el fin del platonismo. Al respecto dirá Heidegger en Sendas perdidas: «Nietzsche concibe su propia filosofía como un movimiento antimetafísico, es decir, antiplatónico». La muerte de Dios es el gran regalo que porta Zaratustra: sumirá a la humanidad en la más grande oscuridad, que será tal que habrá que encender lámparas al mediodía y aun así seguir sin poder ver. Pero ese momento de ausencia de sentido y de valores habrá de ser superado, como veremos, pues al derrumbar todo ídolo quedará el espacio libre para la creación de nuevos valores humanos y será «nuestra más grande alegría» ${ }^{23}$.

En la tercera parte comienzan propiamente las enseñanzas que Zaratustra dirigirá a la masa, y en ese sentido este parágrafo muestra su error inicial: acudir al mercado (Markt) para predicar por vez primera. Ahí va a enfrentar el hecho de que, como lo dirá en «De las moscas del mercado» (Von den Fliegen des Marktes), «... donde acaba la soledad, ahí comienza el mercado; y donde comienza el mercado, allí comienzan también el ruido de los grandes comediantes y el zumbido de las moscas venenosas». Mucho se ha dicho sobre el «elitismo» nietzscheano; helo aquí. Al tratar de convencer a las masas fracasa: su sabiduría es solamente para aquellos que están dispuestos a dejar la comodidad del hombre-masa e iniciarse en el arduo camino a la soledad. Ese camino conduce a la creatividad y con ello a la alegría; mas es necesario saber estar solo y saber disfrutar la soledad, cosa que en un primer momento no es nada fácil: «¿QQuieres marchar, hermano mío, a la soledad? ¿Quieres buscar el camino que lleva a ti mismo? Detente un poco y escúchame», advierte en «Del camino creador». El hombre masa piensa que el que busca, fácilmente se pierde y por ello «todo irse a la soledad es culpa»: aquel que ha formado parte del rebaño durante mucho tiempo, se sentirá culpable al alejarse, por ello será doloroso reconocer que ya no se tiene la misma conciencia que los demás. La masa (el «rebaño») no quiere marchar a la soledad ni le interesa la creatividad. Para Nietzsche el solo hecho de crear, redime. Pero a Zaratustra le interesa la creatividad moral: la capacidad de crear nuevos valores aptos para la vida; nuevas tablas de valores. El mercado, habitado por moscas, es metáfora de los lugares en donde habita la masa, que no se refiere al pueblo vulgar en un sentido peyorativo, sino al hombre común, al hombre-masa, que es el individuo formado y conformado por los estándares dictados por la sociedad: solo frente a este es posible comprender el elitismo nietzscheano.

22. Cf. A. Yáñez, Los Románticos: nuestros contemporáneos, México: Alianza/UNAM, 1993.

23. Cf. La gaya ciencia, $\$ 343$. OC III 858. 
La primera enseñanza que Zaratustra pretende dar a la masa tiene que ver con el superhombre y el gran desprecio. En el mercado al que Zaratustra llega va a tener lugar la función de un bailarín sobre la cuerda floja. La palabra Seiltänzer ${ }^{24}$ alude a un equilibrista danzarín que atraviesa una cuerda tensa. Con su traducción al castellano como «funambulista» o «volantinero» se pierde la idea del Tänzer, el bailarín, y con ello se olvida la importante relación del hombre que va a cruzar la cuerda, con la ligereza de la danza. Zaratustra mismo ha sido ya reconocido por el hombre santo como un bailarín: «Sí, reconozco a Zaratustra... ¿No viene hacia acá como un bailarín?». La danza será una de las virtudes propias del nuevo evangelio zaratustriano, por ello en «De las tablas viejas y nuevas» dirá: «iY demos por perdido el día en que no hayamos bailado al menos una vez!», y en «Los siete sellos» considerará que su virtud es la de un bailarín. En efecto: la danza es la contrapartida del espíritu de la pesadez: la danza es ligera, por ello es una de las virtudes zaratustrianas ${ }^{25}$.

Ante la inminente actuación del bailarín sobre la cuerda, Zaratustra anuncia al superhombre: «Yo os enseño el superhombre»; al igual que el bailarín en la cuerda ha de danzar con pies ligeros para llegar al otro lado, así el superhombre habrá de vencer al espíritu de la pesantez y aprender a danzar, reír y jugar, cualidades propias del superhombre. Übermensch, el concepto más conocido de este filósofo, ha sido traducido por «superhombre» lo cual no es lo mejor, ya que el prefijo súper- alude a la idea de potenciar las cualidades humanas, que no es la idea que Nietzsche pretende transmitir. No se trata de potenciar las cualidades humanas sino de una transformación completamente radical: quedar por encima (über) de lo que hasta ahora ha sido el ser humano (Mensch). Se ha insistido, y con razón, en que quizá se encuentre aquí cierta influencia de Emerson; es conocido el gusto de Nietzsche por los textos de este escritor, en particular por su famoso ensayo The Over-soul. Por otro lado, Mensch no implica un género, como puede ser el caso de

24. La palabra Seiltänzer está compuesta por Seil, cuerda, y Tänzer, danzarín o bailarín: el bailarín atraviesa la cuerda bailando; por ello el hombre que pretenda atravesar la cuerda, deberá hacerlo danzando con "pies ligeros». Insisto en que no debemos menospreciar lo que la danza o el baile significan en esta obra; están ligadas a la ligereza, como se ha explicado. No solo dos capítulos se ocupan específicamente del baile, sino, por citar solamente algunos ejemplos, en «Del leer y el escribir» dirá: «Yo no creería más que en un dios que supiese bailar. Y cuando vi a mi demonio lo encontré serio, grave, profundo, solemne: era el espíritu de la pesadez». Y termina este capítulo diciendo: «Ahora soy ligero, ahora vuelo, ahora me veo a mí mismo por debajo de mí, ahora un dios baila por medio de mí». Y en «La canción de los sepulcros»: «Solo en el baile sé yo decir el símbolo de las cosas supremas», y en «De los tres males»: «el cuerpo flexible, persuasivo, el bailarín, del cual es símbolo y compendio el alma gozosa de sí misma. El goce de tales cuerpos y de tales almas en sí mismos se da a sí este nombre: 'virtud'». Un último ejemplo, en «Al mediodía»: «Así como un viento delicioso, no visto, danza sobre artesonado mar, baila ligero, ligero cual una pluma: así — baila el sueño sobre mí. No me cierra los ojos, me deja despierta el alma. Ligero es, ien verdad!, ligero cual una pluma».

25. Graham Parkes ha realizado la que hoy se tiene como mejor traducción al inglés, y considera, de modo cercano a lo expuesto, que traducir Seiltänzer como tightrope-walker, que es lo usual y lo idiomáticamente correcto, conlleva el alejamiento de la idea de la «danza». Por ello traduce Seiltänzer como rope-dancer, lo cual es una traducción literal que resulta extraña, pero permite conservar la idea de la danza, lo cual, como hemos insistido, es lo filosóficamente indicado. Habría que buscar una expresión castellana nueva para ese término. Al respecto cf. G. Parkes, Thus spoke Zarathustra, Oxford: Oxford UP, 2008. A favor de esta idea está también la interpretación D. Burnham y M. Jesinhausen en Nietzsche’s Thus Spoke Zarathustra, Edinburgh: Edinburgh UP, 2010. 
«hombre», sino la humanidad en su conjunto. El sobrehumano o el ultrahumano podrían haber sido buenas traducciones; pero ya que ir contra una traducción ya establecida resulta casi imposible, nos limitamos a señalar esas posibilidades y algún riesgo: no debemos caer en una interpretación biologicista de esta idea, pues a pesar de que usa un lenguaje casi evolucionista, se trata de un ideal a alcanzar en el sentido intelectual y espiritual.

El superhombre, dice Zaratustra, es «el sentido de la tierra», idea fundamental en esta obra: la tierra tiene un sentido, por lo cual no todo es caos después de la muerte de dios. El sentido de la tierra es la creación del superhombre y pecar contra ello es el peor de los pecados. Antes el sacrilegio era pecar contra dios: hoy el sacrilegio es pecar contra la tierra. Pero la tierra no es un «nuevo valor» humano; es de hecho lo único que «hay». Antes se llegó a creer que el alma era lo más importante y que el cuerpo, anclado en lo terrestre, merecía ser despreciado: pero despreciar al cuerpo crea almas famélicas, dirá Zaratustra, porque el desprecio del cuerpo conlleva el deprecio de la totalidad que es el ser humano. Por eso se requiere ahora un "gran desprecio» hacia los valores establecidos: es necesario que la supuesta dicha de la comodidad moral y la confianza en la razón propia de nuestra cultura, provoquen náuseas. Este concepto, que aparece desde su primera obra, alude al «mareo moral» en el que la humanidad queda sumergida ante el sinsentido de la vida. Ese es un primer paso, tan inevitable como doloroso. Pero es también una primera señal de la llegada del superhombre: quien desprecia los valores establecidos ya intuye algo de orden superior. Como un aviso del fracaso de Zaratustra, al final de esta sección el pueblo le calla y pide a gritos que se proceda al espectáculo público.

Zaratustra expone entonces la metáfora entre la cuerda y el superhombre con fuertes tintes evolucionistas: el ser humano es como una cuerda tendida entre el animal y el superhombre; en asumirse como tal está su grandeza y por eso mismo el ser humano puede ser amado como un paso hacia superhombre. La cuerda, se nos dice, está tendida sobre un abismo, y ya lo dirá en «De los sabios famosos»: «No sois águilas: por ello no habéis experimentado tampoco la felicidad que hay en el terror del espíritu. Y quien no es pájaro no debe hacer su nido sobre abismos». La idea del abismo aparece ligada a la ligereza necesaria para cruzarlo. El espíritu de la pesadez cae en él: un ser alado, lo sobrevuela ${ }^{26}$. Por ello la grandeza del hombre consiste en ser un puente, un tránsito, un ocaso.

Una vez establecido esto comienza un discurso de 18 sentencias que comienzan con «Yo amo a...». Resulta imposible no notar el tono bíblico de este parágrafo: el Sermón de la montaña bíblico comienza de una manera muy similar: «Benditos aquellos que...»; en este parágrafo la fórmula es: «Yo amo a...». El objeto de ese amor no es el superhombre, sino precisamente el hombre como tránsito hacia el superhombre. Las 18 oraciones podrían resumirse en una: yo amo a aquel que vive

26. De modo similar esta idea aparece en el poema «Los rapaces», de Los ditirambos de Dioniso: «hay que tener alas cuando se ama el abismo» («Man muss Fluegel haben, wenn man den Abgrund liebt»). Cf. Los ditirambos de Dioniso, KSA 6, 390. 
trabajando para la llegada del superhombre; esto es: yo amo a aquel que desprecia los valores establecidos y trabaja para que algún día la humanidad viva con nuevos valores, valores vitales que no desprecien la vida. Por ello es posible amar a los grandes despreciadores de lo establecido, porque ellos serán los nuevos instituidores de valores fieles al sentido de la tierra. En estas 18 declaraciones se anuncian ideas capitales que se explicarán a lo largo de la obra. Encontramos nuevamente ideas que habían aparecido: el sentido de la tierra y la necesidad de dejar de buscar los valores "detrás de las estrellas», la idea de una única virtud, la cual siempre será más fuerte que dos, la idea de donación por sobreabundancia, entre otras ya anunciadas. Pero aparecen también ideas nuevas, de capital importancia. La idea de vergüenza, como lo han hecho notar Burnham y Jesinghausen ${ }^{27}$, había sido anunciada desde el punto de vista del superhombre: el ser humano es una vergüenza para él. Para estos exégetas esta vergüenza se explica en la oración número 11: se siente vergüenza porque los dados han caído a favor del ser humano, quien se ha estancado como tal y por ello no puede acceder a las virtudes y la forma de ser propia del superhumano o superhombre; el ser humano se ha tornado estático en su dominio de la tierra, en lugar de continuar su evolución hacia el superhombre. Vuelve a aparecer la idea del ocaso, de aquel que vive declinando como el Sol de la tarde, que es el único camino para el nuevo amanecer. Para ello hay que ser un «gran despreciador» del pasado y apuntar al futuro. El gran desprecio del presente conduce a la muerte como el Sol del atardecer conduce a la noche. Por eso es necesario untergehen, caminar hacia abajo y completar el círculo como lo hace el Sol hacia el nuevo amanecer. Todo esto puede resultar poético, pues es metafórico, pero en el fondo lo que anuncia es una compleja idea que dará pie a múltiples interpretaciones por ser la idea más radical de la obra: la relación entre el superhombre y el eterno retorno de lo mismo.

Hacia el final de este parágrafo se anuncia a los «espíritus libres», idea que en obras posteriores se tornará sumamente compleja y que en esta obra en cambio expone con mayor claridad. Quien es de espíritu libre y corazón libre, dice Zaratustra, tiene a su cabeza como la entraña misma de su corazón, que le impulsa a su ocaso para el nuevo amanecer. Tener la cabeza como entrañas del corazón conlleva la idea de pensar desde las entrañas mismas, pensar con el cuerpo, pues, como dirá más adelante, somos cuerpo y nada más: eso lo sabe el despierto ${ }^{28}$. Y junto a esta oración, el parágrafo cierra con la idea de la luz: ella proviene de la oscuridad como el luminoso trueno proviene de una nube negra. El superhombre como un ser luminoso o iluminado, como hemos visto, es una referencia continua en la obra.

En el quinto parágrafo asistimos al primer fracaso de Zaratustra: el pueblo no sabe escucharle. Zaratustra «no es boca para esos oídos». Pues cंcómo comprender al profeta del gran desprecio cuando lo que existe es un "gran orgullo» de la propia formación, de la propia moral, religión, filosofía y ciencia? Aquello de lo cual el

27. D. Burnham y M. Jesinhausen, op. cit., p. 22.

28. Cf. Za I, «De los despreciadores del cuerpo». 
ser humano está orgulloso es lo que para Zaratustra es lo más despreciable y representa al último de los hombres en la escala de gradación moral. Y a este le habla ahora Zaratustra; todavía es posible para el ser humano fijarse una meta y sembrar con ello su más alta esperanza. Todavía es posible, pero se acerca el tiempo en que esto ya no será posible, el tiempo en que ese último hombre reinará y de acuerdo a sus modos, todo lo empequeñecerá: es el reinado absoluto del hombre que Heidegger llamará el de la cotidianidad media, el hombre-masa. Él ha inventado su «pequeña felicidad» y se siente orgulloso de ella, mas esta le ha llevado a ser mediocre hasta en sus pecados ${ }^{29}$. Lo terrible de ese último hombre es que clausura la posibilidad de un desarrollo posterior, le niega el paso al superhombre. Ese último hombre representa la confianza en la comodidad de la moral vigente, que surge cuando el hombre responde a la necesidad de compañía de manera gregaria. Con ello el ser humano sacrifica su dignidad más elevada: la de ser digno de darse sus propias normas. Aparece una idea que será importante en «De las cátedras de la virtud»: el sueño de los justos es el de aquellos que duermen bien gracias a un poco de veneno: la moral establecida.

$\mathrm{Al}$ aferrarse a su pequeña felicidad, su cotidianidad media y su moral establecida, el último de los hombres se ha aferrado a ideas fijas y ha perdido la posibilidad de cambiar. Su mundo es ordenado y estable, pero es necesario un poco de caos para concebir «una estrella danzarina». En su ordenado mundo el último de los hombres «parpadea» ante sus inamovibles inventos. Decir que ese hombre «parpadea» es una burla de Zaratustra al orgullo que ese hombre siente por sus creaciones: él parpadea orgulloso de aquello que Zaratustra más deprecia ${ }^{30}$.

La sección concluye con una segunda burla de la muchedumbre a Zaratustra, «idanos al último hombre, al superhombre te lo regalamos!», esto es: danos la comodidad, la estabilidad y la vida fácil que no requiere de cuestionamiento alguno. ¿Sacrificamos en ellos nuestra capacidad creadora? Poco importa: todo cuanto Zaratustra considera lo ínfimo, es precisamente lo que la multitud desea: el confort de una moral establecida. Por ello en el fondo esa multitud que desea los valores y el modo de vida del último de los hombres, representa ya de hecho al último de los hombres. Todo esto provoca una honda tristeza en Zaratustra, quien vuelve a hablar a su corazón: los hombres no le escuchan, no le comprenden e incluso le odian.

Con esta sección comienza la segunda parte del Prólogo: ha concluido la primera enseñanza y Zaratustra ha enfrentado a una muchedumbre que no puede ni

29. A raíz de los estudios comparados entre Nietzsche y el taoísmo, que han adquirido importancia internacional, es importante aclarar que esta "pequeña felicidad» no se refiere a aquella que puede tenerse a través del disfrute de la sencillez de la vida; se refiere a la felicidad estandarizada por la sociedad actual y es, como se verá, una falsa felicidad.

30. En su ya citado estudio sobre la obra que nos ocupa, Burnham y Jesinhausen consideran que el parpadeo puede tener otras interpretaciones: puede ser la imagen de la estupefacción o de un tic que señalara cierta degeneración. Cabe la posibilidad, observan, de que aluda al momento presente, ya que Augenblink en alemán significa «momento» y el último hombre blinzelt (parpadea). Cf. D. Burnham y M. Jesinhausen, op. cit., p. 24. 
quiere escucharlo. El comienzo de esta segunda parte es remarcado a través de un cambio radical en la narrativa, la cual retorna a la acción del bailarín sobre la cuerda, cuyo espectáculo había ya comenzado. Estos cambios en la narrativa serán una constante a lo largo de todo el libro; Nietzsche irá de la historia narrada, a los diálogos interiores, a los poemas y los aforismos.

Cuando el danzarín está a mitad del camino sobre la cuerda aparece un bufón. La imagen del bufón reaparecerá a lo largo de la obra no siempre con el mismo significado, o más bien habría que decir, en cada momento en que aparece lo hace ampliando su significado ${ }^{31}$. El bufón salta sobre la cuerda a grandes pasos, le insta a moverse más rápido y al acercarse grita como demonio y brinca por encima del danzarín, que pierde el equilibrio y cae precisamente junto a Zaratustra, que no se había movido de su lugar, contrariamente a la muchedumbre que había corrido asustada. Es notable que el bufón no tire al danzarín equilibrista: este cae ante el espanto de ser superado, adelantando con esto la frustración y la envidia del joven de la montaña en la primera parte de la obra.

Zaratustra se arrodilla al lado del moribundo, quien le dice que está a punto de irse al infierno. Pero el sabio le explica que no hay tal cosa: el alma morirá antes que el cuerpo, no hay nada que temer. El moribundo considera que si eso es verdad, no se pierde nada al morir, pues en vida no seríamos nada más que animales amaestrados. Pero Zaratustra le pedirá no decir eso: «Tú has hecho del peligro tu profesión y por ello te enterraré con mis propias manos», le dice. Hacer del peligro la propia profesión es la metáfora del intento por llegar al superhombre. La multitud y el mercado están abajo y el danzarín arriba. La multitud está estática y no comprende siquiera lo que es el superhombre: el danzarín se atreve a intentar cruzar de un lado a otro, lo que equivale, tal y como se dijo anteriormente, ir del hombre al superhombre. Por eso para Zaratustra este hombre es digno y se propone enterrarlo con sus propias manos, promesa que, como veremos, no cumplirá por razones específicas.

Este breve apartado no presenta novedad en cuanto a la acción de Zaratustra, quien aparece sentado junto al cadáver todo el tiempo. Sin embargo los datos filosóficos son muy significativos. El pueblo se retira, Zaratustra queda solo; comienza el momento en que puede hablar en soledad. A lo largo del libro esta será una constante; Zaratustra habla con su corazón: no dialoga, no reflexiona, sino que le dice algo a su corazón: no a su razón o pensamiento. Este breve apartado adelanta ya la superación nietzscheana del pensamiento de Schopenhauer, que se patentizará en la obra. La vida en efecto no tiene sentido; la existencia es siniestra al grado en que hasta un bufón le puede resultar fatal. Hay por supuesto un contraste entre el heroísmo de aquel que quiere cruzar la cuerda, esto es, de aquel que intenta llegar a ser superhombre, y lo absurdo que puede ser la existencia que hasta un mero bufón, hasta mera mala suerte acaba con el más noble intento. Pero eso no implica que la vida humana deba ser un mero sinsentido, ni tiene por qué

31. Reaparece como veremos en el mismo Prólogo, así como en los libros I y III. 
oscilar entre el dolor y el aburrimiento, como Schopenhauer llegó a considerar; el sentido de la tierra es el superhombre, o en otras palabras: somos capaces de crear valores morales siempre nuevos que respondan a la vida, a la vida de esta tierra en que vivimos, ya que no hay otra. Zaratustra quiere enseñar el sentido de la vida y el superhombre. Ya desde su primera obra había insistido en que la vida es trágica en el sentido específicamente nietzscheano: es unión y aceptación de placer y dolor. Ello ya implicaba una superación del pesimismo de Schopenhauer; la vida no oscila entre el dolor y el aburrimiento, como lo creyó ese pensador. No en balde esa obra se subtitulaba «De cómo los griegos superaron el pesimismo»: todo el libro versa sobre cómo superar el pesimismo. Ahora Zaratustra lo declara radicalmente: la vida requiere de una meta que brinde una esperanza y le dé sentido, y la más loable es la creación del superhombre.

Este apartado concluye con un Zaratustra que se da cuenta de que los hombres están muy lejos de él como para comprenderle: «Oscuros son los caminos de Zaratustra», dice empleando lenguaje bíblico nuevamente, y se retira cargando el cadáver.

Son tres las escenas de importancia narrativa y filosófica en este apartado: la reaparición del bufón, el encuentro con los sepultureros y finalmente la petición al hombre insomne y su respuesta. La imagen del bufón se ve enriquecida al aparecer como portavoz de una amenaza; Zaratustra que debe irse de la ciudad, pues son demasiados los que le odian: le odian los buenos, los justos y los creyentes. Se ha salvado de ese odio por humillarse al «hablar como bufón» y llevarse consigo al «perro muerto». Pero viene la amenaza: ahora debe abandonar la ciudad o mañana, dice, «saltaré sobre ti, un vivo sobre un muerto». Su amenaza remite a la advertencia del eremita sobre los castigos para los incendiarios: ahora el bufón le advierte que se le considera «el peligro de la muchedumbre»; para ellos Zaratustra es un ladrón. Esa imagen es recurrente; Zaratustra es el que «roba» la vieja moral y deja a la multitud desposeída de su tan amada formación y cultura.

Zaratustra continúa a través de calles oscuras hasta la puerta de la ciudad en donde se encuentra con los sepultureros, que se burlan de él y entre burlas vuelven a llamarle ladrón. Ellos, que tratan con muertos, pueden interpretarse como aquellos que lidian con conceptos muertos, y se les asocia por lo general con historiadores o filósofos ${ }^{32}$. Pero tomando en cuenta la compleja relación de Nietzsche con la filología, es posible también que se refiriera a ellos, quienes por cierto al final «juntan sus cabezas» para murmurar.

Ya fuera del poblado, entre ciénagas y bosques, escucha el aullido de los lobos hambrientos y siente hambre. No se trata de cualquier tipo de hambre, como resulta evidente a través de las reflexiones de Zaratustra al respecto: «Extraños caprichos tiene mi hambre». A Zaratustra los lobos le contagian el hambre, no le causan temor, al igual que sucederá, como veremos, al final de este apartado, cuando al quedarse dormido inicia la epifanía con la cual culminará este Prólogo.

32. Tal es el caso de Martín Zubiría en Nietzsche. Mundo amado, amada eternidad, Buenos Aires: Ediciones del signo, 2009, p. 27. 
$\mathrm{Al}$ encontrar una casa solitaria toca la puerta y el hombre insomne responde: «¿Quién viene a mi casa a interrumpir mi insomnio?». Este insomne es un eremita también, y no duerme: ya no duerme en paz pues ya no tiene las virtudes de la masa, tema que como mencionamos será desarrollado en «De las cátedras de la virtud». Este eremita esboza al hombre superior de la cuarta parte: aquel que aunque se ha apartado de la masa, no ha creado aun valores propios del superhombre. Zaratustra responde anunciando a «un vivo y un muerto», pide comida y bebida, y el eremita le da comida a ambos sin distinguir entre el vivo y el muerto, repitiendo una conocida oración del evangelio de $\mathrm{Mateo}^{33}$. Nótese que Zaratustra sigue caminando sin problemas durante la noche, pero al comenzar el amanecer se pierde en el profundo busque y deja de caminar. Es entonces cuando deja al muerto en un tronco para salvarlo de los lobos, sin sentir él temor hacia ellos, como si el muerto requiriese de más protección que él, y se tiende a dormir.

9

Cada vez que en la obra Zaratustra se queda dormido tendrá una revelación. Continúa dormido durante la aurora y la mañana hasta despertar al medio día, momento en que el Sol está en su cénit y que anuncia ya la importancia del «gran mediodía» esperado por Zaratustra ${ }^{34}$. Se levanta deprisa «como un marino que avista tierra»: ha tenido una epifanía. Lo que Zaratustra ha comprendido es que él no necesita cargar con muertos que lleva a donde lo desea, sino que requiere compañeros vivos, que si le siguen lo hagan porque quieran seguirse a sí mismos. No deberá por lo mismo hablarle al pueblo, a la masa, ni debe ser «pastor» ni perro de rebaño alguno; nueva referencia a la figura de Jesús, quien en efecto se consideró pastor de un rebaño. Comprende entonces que para el pueblo él será un ladrón, un criminal, un delincuente que romperá las tablas de valores ${ }^{35}$.

Zaratustra está listo para emprender su viaje; sabe que debe buscar acompañantes creadores, y para ello hablará con eremitas y parejas de ermitaños: nunca más hablará al pueblo o a la masa. Ha tenido ya un primer compañero: aquel que ahora lleva cargando, y por eso le dice: «Y tú, mi primer compañero, idescansa en paz!». Zaratustra se propone no volver a hablar jamás ni con el pueblo, ni con un muerto: compañeros de viaje vivos que sean sus colaboradores; eso es lo que de ahora en adelante buscará. Ahora Zaratustra mismo «saltará por encima» de los vacilantes y no dejará de caminar en búsqueda de sus compañeros.

En esta última sección reaparecen los dos animales acompañantes de Zaratustra y la alusión al eterno retorno de lo mismo es ahora sí completamente clara: el águila

33. Mateo 10, 42. Al respecto cf. M. Zubiria, op. cit., p. 28.

34. Esto se confirma al inicio del apartado 10: «... el sol se encontraba en su cénit».

35. La constante repetición de esta expresión es sin duda una referencia a las tablas de la ley bíblicas; no olvidemos que Moisés mismo rompe las tablas después de permanecer cuarenta días en el monte Sinaí Cf. Éxodo 32,1-35. 
vuela en círculos y en su cuello va enroscada una serpiente. Tenemos aquí las dos imágenes de lo más elevado y lo más rastrero que se unen en esta metáfora como una premonición de un estar más allá del elevado bien y del bajo mal: lo más elevado y lo más rastrero van unidos y son, a la par, los amigos de Zaratustra.

Esos animales reaparecerán a lo largo de la obra en momentos clave, pero por lo pronto ellos le guiarán ya que, dice, «he encontrado más peligroso el trato con los hombres que con los animales». El apartado concluye diciendo: «Así comenzó el ocaso de Zaratustra», y como se verá, en el tercer libro se encontrará la fórmula "Así acabó el ocaso de Zaratustra» ${ }^{36}$. El ocaso de Zaratustra, su Untergehen necesario para que, al igual que el Sol, se pueda pasar al otro lado, al nuevo amanecer del superhombre. Ese nuevo amanecer se anuncia en el último apartado, «El signo», en el cual Zaratustra comprende que si bien no ha encontrado a sus compañeros, ellos están por llegar.

¿Quiénes son, pues, esos nuevos compañeros de viaje que anuncia este Prólogo y que ocupan toda la búsqueda zaratustriana a lo largo de la obra? En la obra siempre fueron «aquellos que están por llegar». Pero hoy podemos afirmar que esos ansiados compañeros, que le siguen porque quieren seguirse a sí mismos, son, qué duda cabe, quienes ahora intentamos tomar sus enseñanzas. Nietzsche llegó a considerar que algún día las universidades establecerían cátedras para su Zaratustra. Quienes lo hemos hecho, sabemos que como Lou von Salomé se lo dijo al mismo Nietzsche cuando este se encontraba ya enfermo, su tiempo apenas estaba por llegar ${ }^{37}$.

36. Cf. Za III, «El convaleciente».

37. Cf. P Rivero Weber, Nietzsche y su música, Estudio introductorio, México: UNAM, ${ }^{62015}$, p. 3. 